\title{
The Paradigms of Traditional Educational Culture in the Context of Liquid Modernity: An Empirical Study
}

\section{Francisco Alberto Severo de Almeida1, Paula Cinthia de Oliveira Marques², Jorge Manoel Adão, Zenaide Dias Teixeira', Marcelo Duarte Porto ${ }^{1}$}

${ }^{1}$ Universidade Estadual de Goiás (UEG), Luziânia, Brazil

${ }^{2}$ Secretaria de Estado de Educação de Goiás, Goiânia, Brazil

Email:smfsevero@gmail.com

How to cite this paper: de Almeida, F. A. S., Marques, P. C. de O., Adão, J. M., Teixeira, Z. D., \& Porto, M. D. (2019). The Paradigms of Traditional Educational Culture in the Context of Liquid Modernity: An Empirical Study. Creative Education, 10, 784-795.

https://doi.org/10.4236/ce.2019.104058

Received: March 14, 2019

Accepted: April 25, 2019

Published: April 28, 2019

Copyright $\odot 2019$ by author(s) and Scientific Research Publishing Inc. This work is licensed under the Creative Commons Attribution International License (CC BY 4.0).

http://creativecommons.org/licenses/by/4.0/

\begin{abstract}
This scientific essay presents the results of the empirical research on the relations between traditional educational culture and the postmodern context in Luziânia's high schools, where the aim is to comprehend the contradictions between traditional pedagogical and contemporary tendencies applied to public schools. It reviews bibliographically from the perspective of different Brazilian education thinkers to discuss the paradox between traditional educational culture and the postmodern context, with a goal to investigate the relationship between the theoretical basis that supports the characteristics of traditional liberal pedagogical culture and the current scenario. The field research was held through the application of a structured questionnaire, as a basis in the construct denominated Conceptual Model of study of the paradigms of traditional educational culture in the context of liquid modernity, with questions closed and based on the Likert scale. At last, it highlights that the empirical evidences of research indicate that in light of the social, economic and cultural context of the rapid and complex transformations of postmodern society, there is still a predominance of traditional liberal pedagogical thinking. Thus, based on this research, it is inferred that the paradigms of traditional education overlap with the thoughts and dynamics of society inserted in the context of liquid modernity.
\end{abstract}

\section{Keywords}

The Traditional Education Culture, Liquid Modernity, Paradigms of Education 


\section{Introduction}

The contemporary education is very peculiar, since, probably for the first time in history we realize that the differences between cultural traditional and modern aspects are dissociated by the lack of an effective model that contemplates the necessary dimensions for the educational process. The crises and evidences of current education have extensive relationships with the deepest paradigmatic crises in the field of the modern capitalist system. If, on the one hand, we have paradigms with many traditional aspects in common, which are solidified by modern signs, on the other hand, they hold a personal history because they deal with specific issues, whose crises probably devastate the most diverse sectors of society, since society has been going through considerable social transformations.

In this perspective, it becomes a challenge to understand the intense crises that multiply in the education field, regarding the construction of different standards that are providing different postures between the traditional pedagogical tendencies and those of the contemporaneity. In Bauman's (2013) conception, the crisis of contemporary education is very peculiar because, probably for the first time in modern history, we realize that the differences between traditional and modern aspects and the lack of a universal model have come to stay. In this context, Lima (2010: p. 2) leads the reflection on the topic when he affirms that we are facing a scenario of theoretical, social, economic and cultural fragmentation which rebounds on about the educational scenario: "[...] the removal of the foundations of pedagogical discourse that supports educational practices at school, whether they are considered progressive or conservative." These crises produced and reproduced by the cultural changes in the contemporaneity have released discussions about the paradigmatic transformations and make reference by postulating the passage from Solid Modernity to Liquid Modernity.

However, the 21st century education, placed in the context of Liquid Modernity, follows the labor market model and is based on the technological advances of cognitive computing associated with artificial intelligence. In this context, traditional education and wisdom have lost their fundamental value and people concerned with learning and their promotion have had to shift their focus of attention. It is the paradox of contemporary education: develop the talent of learning quickly and the ability to instantly forget what has been learned. The information is discarded quickly; knowledge becomes shallow and superfluous. To this end, thus, one can discuss the antagonism of the relations and conflicts of traditional educational culture and liquid modernity in high schools. This contradiction is latent among educators.

Within such concept, this scientific essay presents the results of the empirical research on the relations between the traditional educational culture and the postmodern context in Luziânia's high schools, where one tries to comprehend the contrad ictions between the pedagogical, traditional and contemporary ten- 
dencies applied to public schools.

\section{Theoretical Contribution}

\subsection{Traditional Liberal Pedagogy}

The historical context of Traditional Liberal Pedagogy emerged in the early nineteenth century, where directions were restricted in socially imposed truths, with accumulations of content and rigid discipline, to which the teacher was the holder of all knowledge and had as an obligation to pass on that knowledge, without worrying about the cognitive ability of their students. The introduction of the denomination "Traditional Pedagogical Conception or Traditional Pedagogy was introduced with the advent of the renovating movement that marked the novelty of the proposals that began to be transmitted and classified as 'traditional' the conception until then dominant" (Saviani, 1983).

Based on enlightenment ideas, Traditional Liberal Pedagogy was the base of school education and has maintained its influence to this day. This tendency emerges as an alternative to the medieval, religiously based school. In this period, there is a moment of exaltation of reason and freedom, the devaluation of faith and the exaltation of reason, the moment of science. It is in this context that John Locke develops a new conception of education, emphasizing the role of the master in providing productive experiences that assisted the correct use of reason. To that end, the school should focus on the teaching of fragmented disciplines and, especially, on the preparation for the development of trade, aiming at the practical life, which would guarantee the advance of the liberal capitalist ideals of this period of time.

The term liberal does not have the meaning of "advanced," "democratic," "open," as it is often used. The liberal doctrine appeared as justification of the capitalist system which, in defending the predominance of freedom and the individual interests of society, established a form of social organization based on private ownership of the means of production, also called class society. Liberal pedagogy, therefore, is its own manifestation of this type of society according to Libâneo (1984).

To ensure the best development of this knowledge, this tendency proposes five formal characteristics: preparation-review of the previous content; presentation - the teacher verbalizes new knowledge; assimilation-the student connects the new with the old, noticing similarities and differences; generalization-the student constructs abstract conceptions from his/her experiences; evaluation-repetitive exercises and tests in which the student applies what he has learned.

The commitment of the school is to promote a purely moral and intellectual formation, shaping the student for social coexistence, having as an assumption the conservation of society in its current state (status quo), the social problems belong to society this tendency compromises the socio-political transformation, since there are no questions and no critical thoughts, individuals will only be able to repeat what has been passed on to them in any discipline, which only de- 
velops memory and retention of information. Working critical and reflective thinking is in second plan, so that students do not notice every alienating and excluding process present in the capitalist society.

The Traditional Pedagogy that Libâneo shows is one that does not respect the individualities of the student and that makes teaching stay away from reality. For that reason, the urge and concern that education should start from general to private, making education a dynamic and meaningful process for students.

Such pedagogy is marked by an education based on the imposition of ideas that are ready and the contents passed on have concrete social values and well determined by society and ordered in legislation regardless of the social experience of the student. In this educational context, the teacher is seen as a disciplinarian in the classroom, and there is virtually no relationship between him and the students. The teacher is the holder of knowledge and the students are static listeners, without specificities, experiences or opinions.

According to Libâneo (1984), we can see that traditional liberal pedagogy is based on the knowledge of the master/teacher, in a "magistroccentric" character, that is, the teacher has all the authority, since it is he who holds the knowledge, and it is up to him to pass it on to the students. It is a vertical relationship, in which the student is the receptor, and the teacher, the holder of all historically constructed knowledge. The student is educated to achieve his fulfilment, through his own effort.

With that in mind we can notice that the education came directly from the teacher who did not care about the student, but with the knowledge passed on. Those less capable students should look for a course that would be more vocational, that is, a course of pure teaching without human development. We see, then, that the educational process was responsible only for the intellectual formation of the student, which he did not have the power to contest or give his opinion, in this case he could only get the function of raw and decorative learning, and the teacher the function of direct teaching and without delayings.

The methodology, content and evaluation were all of teachers' decision-making power and oral explanation was the basis of knowledge sharing. The transfer of learning depended on training, being essential to retention and memorization, so that the student responded to new situations in a similar way to previous situations. It can be affirmed that for the traditional pedagogical context there is a decrease in the educational process, restricting it only to one of its dimensions: the dimension of knowledge. Another predominant factor was rigid discipline, which relied on the force of teacher's imposition and with the school's strength, where people were educated in a way that they could become responsible, morally strong, well-prepared human beings to live rigidly as it was imposed.

The school is not different from the others, it is realized that the rigidity and good use of the body are slogans that make the discipline a way of obtaining the increase of productive efficiency. For the author, the historical moment of the subjects is the moment in which an art of the human body is born that aims not 
only the increase of its abilities, nor to deepen its submission, but the formation of a relation that in the same mechanism makes it so much more obedient as it is most useful, and vice versa (Foucault, 1997).

The verbal orders present in the school's routine revealed the controlling of behaviors, where the students had to act equally according to a signaling that was ordered to them. The way to sit in the chairs and use the material almost automatically was also a referential of the explicit use of powers.

\subsection{Education in Post Modernity}

Since the 1980s, relationships are more economic, flexible and creative. Society goes through a period of intense changes and innovations, both in the scope of technologies, as well as in the moral and socio-cultural sphere, whose effects and reflexes have shaken the traditional and conservative standards seen until then.

Thus, various certainties are dissolving, and these are no longer capable of reflecting the engaging of relations between man, society, and all other aspects essential to human life. Then comes the immediate and temporary aspects capable of transforming the interaction of man with his peers and with the environment, this challenge induces us to a temporary existence, short-sighted, but without great prospects for the future.

According to Bauman (1997): "Immediate modernity is 'liquid' and 'fast', more dynamic than the 'solid' modernity that has overweighed. The passage between one and another caused deep changes in all aspects of human life. The liquid modernity would be a world full of confused signals, prone to change quickly and unpredictably."

Therefore, from these events, we need to understand the urgency of adapting and enabling ourselves to this new reality. Everything revolves around competitiveness and exclusion, education is the only means capable of building a society of conscious and competent individuals who value and respect their peers and life in general.

Through the whole context of the "new society" we can say that Education is not free from the transforming influences of globalization. Cultural postmodernity is perceptible and profound and there is an existing connection between Postmodernity, globalization and education, since everything is related to the market logic, so essential being the maintenance of the global economy.

To meet the requirements of a new job market it is necessary to analyze the potentialities and the cognitive process of each student. Education must take the path of the new and reconfigure the school curriculum by analyzing the fragmentation and the segmented process coming from traditional modern culture.

In face of this complex system of conflicting conditions, educators and education researchers need to analyze the urgent need to adopt new postures in order to adjust and adapt the teaching-learning process of individuals. To do this, it is necessary to understand that all that was known about traditional teaching practices and methodologies, no longer serves the purpose of the current context. 
The major aim of education to advance in the educational aspect is the $\mathrm{Na}$ tional Curricular Common Base (BNCC). The document reconfigures the entire curriculum by determining competency related to digital culture, relevant skill that has to do with critical, meaningful and reflective technology. It is to reprogram education together with the amount of information that is increasingly accelerated. The technological, political and social revolution occurs first in the school space and this aspect influences directly the existing social gap between technology and the regression in learning.

For Canário (2005: p. 208) "The main resources of Education are the people, the knowledge and the mobilizing experiences. Hence, there are no poor schools." In this sense, the postmodern school supposes, therefore, the adoption of the inverse procedure that is to transform students into people. Only under such conditions can the school take over as a place of authority, knowledge and pleasure.

The reform of teaching and thought is a historic project; it will, of course, be a challenging process. It is a work that must be undertaken by all educational institutions, which involves the training of tutors and self-education of teachers. Based on this scenario, only the self-knowledge of teachers will not be enough to answer the great question left unanswered by Karl Marx: "Who will educate educators?".

The holistic understanding of education must be decisive in the transformation of relevant knowledge, since society, school and the individual are inseparable and there is the interdependence and interactivity between the object of knowledge and its context.

Knowledge is not relevant because it contains a great deal of information. The real problem is not the quantitative information, but the information organization. It is the contextualization that always makes pertinent knowledge possible, hence the need to teach pertinence, that is, a simultaneous analytical and synthetic knowledge of the parts reconnected to the whole and of the whole reconnected to the parts (Morin, 2000).

The contemporary scenario places us in front of the inability to obtain absolute answers to support the questions related to life, in a conjuncture of the declining of ethical life models. For the educational context, this scenario is not different, unleashing difficulties to sustain theoretical and practical choices that will anchor the teaching performance (Lima, 2010).

It is reasonable to say that we are living in a postmodern culture where individualism, consumption as the essence of social relations, individual and political crises coexist in a time that can not be considered modern anymore. Structural changes undertake the individual's thought reform and the way in which he absorbs his reality. To reconcile what was previously treated in isolation and unrelated to the context, it will depend on a cultural society change.

These changes need a coherent and complex pedagogical approach. This is because it refers to the idea of a spiraling pedagogical circuit, which advances by going from the parts to the whole and from the whole to the parts (Morin, 2000: 
p. 52). Such practical flexibility facilitates the contextualization and transdisciplinarization of the contents covered, which, according to Morin (2000), allows to create the exchange, cooperation and policompetence.

It is also agreed that the idea of transdisciplinarity cannot be done in any way. It becomes necessary to reconcile the transdisciplinary principle with the complexity paradigm. That way, the pedagogical practices accomplished in this perspective would be controlled and directed intentionally with what is being proposed.

In the epistemological field, all the aspects that interfere in the educational process must be considered and not only to the teaching performance. It is useless to propose new methodological conceptions if the conditions under which they will be applied remain unchanged.

\section{Methodology}

The presented articles of exploratory and descriptive character, with a bibliographical and field research basis. The bibliographic review is based on the prism of different educational thinkers to discuss the paradox between the traditional educational culture and the postmodern context, with the purpose to investigate the relation between the theoretical base that supports the characteristics of the traditional liberal pedagogical culture and the current scenario. The approach to traditional educational culture is grounded on a bibliography of contemporary articles. The field research was held through the application of a structured questionnaire, with 19 questions, with questions closed and based on the Likert scale. Teachers could answer only one of the alternatives for each question. The questions were elaborated as the basis of the construct denominated Conceptual Model of studied paradigms of traditional educational culture in the context of liquid modernity (Figure 1).

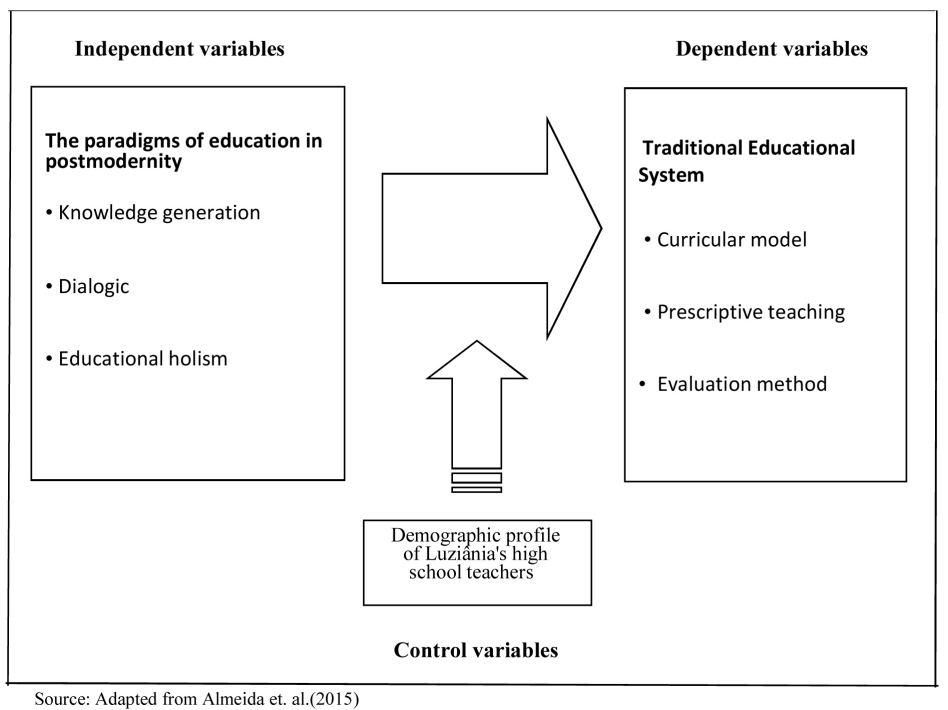

Figure 1. Conceptual model of study of the paradigms of traditional educational culture in the context of liquid modernity. 
The respondents were teachers from state high schools in central Luziânia, whose access was facilitated by the Principals and Vice-Principals of these institutions, who sent the printed version of the questionnaires to the teachers who were in loco at the time of the research. There were printed out 120 questionnaires, of which 52 were answered, a sample considered enough by the authors, for the purpose for which it was intended.

\section{Research Results}

Of the seven high schools surveyed, only one school has a three-shift teaching modality, and it has technical occupational education in connection with high school at night. About $44 \%$ of the professors has their complete graduation; only $6 \%$ have incomplete degrees, $38 \%$ have specialization and $12 \%$ of professors have masters degrees. It was also investigated, within the demographic profile of the teachers, the time of teaching performance in the classroom; whether or not they work in their area of training and the type of employment relationship they have with the State of Goiás. All teachers studied have a degree that gives them a license to teach, with $68 \%$ working in their area and $38 \%$ teaching another specific discipline other than their own graduation. Of these teachers, $66 \%$ are temporary contracts, $32 \%$ are public effective servants and only $2 \%$ are in substitution for some kind of license. The time spent in the classroom has an interesting percentage, with $26 \%$ of teachers working from zero to five years, $46 \%$ between five and ten years, $9 \%$ from ten to fifteen years and $19 \%$ for more than fifteen years in class.

The analysis to identify signs of traditional educational culture traits in the postmodern context was based on the seven knowledges needed to educate the future of Edgar Morin (2000). The research was based on a Conceptual Model of the study of traditional educational culture paradigms in the context of liquid modernity and its research variables, based on a set of questions that pointed to the presence of characteristics of a traditional organization, whose results are presented in Table 1.

In the questions' analysis that punctuated the considered characteristics of the traditional educational culture dimension, therefore, they are in agreement with the standards of the bibliographical researches fulfilled. There are evidences of the school organizational culture of the nineteenth century and indicates practices of the traditional liberal pedagogical approach in the schools surveyed: For $48 \%$ of the teachers the curriculum is strict and prescriptive, and $65 \%$ of the respondents consider the curricular instruments repetitive and of content reviewing; $63 \%$ believe that both the evaluation system is the reflection of the personalization of education; $84 \%$ of this sample affirms that the student's interest is only to pass a grade without worrying about the proficiency of knowledge. Teachers agree in $79 \%$ that the object of the curricular instrument is to guide the work in the classroom. Finally, considering the variables analyzed related to the level of agreement responses, marked, in their greater expression above $60 \%$ by 
Table 1. Analytical logical structure matrix of the traditional education dimension.

\begin{tabular}{|c|c|c|c|c|c|}
\hline \multirow{3}{*}{ Dimension } & \multirow{3}{*}{$\begin{array}{c}\text { Variable } \\
\text { analyzed }\end{array}$} & \multirow{3}{*}{ Questionnaire Item } & \multicolumn{3}{|c|}{ Teaching perception } \\
\hline & & & $\begin{array}{c}\text { Level of } \\
\text { Disagreement }\end{array}$ & Neutral & $\begin{array}{c}\text { Level of } \\
\text { Agreement }\end{array}$ \\
\hline & & & $\%$ & $\%$ & $\%$ \\
\hline \multirow{7}{*}{$\begin{array}{l}\text { Traditional } \\
\text { Education }\end{array}$} & \multirow{3}{*}{$\begin{array}{l}\text { Traditional } \\
\text { Curriculum } \\
\text { Model }\end{array}$} & $\begin{array}{l}\text { The current curricular } \\
\text { model is strict and } \\
\text { prescriptive }\end{array}$ & 22 & 30 & 48 \\
\hline & & $\begin{array}{l}\text { The purpose of any } \\
\text { curricular instrument is to } \\
\text { guide the teacher's work }\end{array}$ & 6 & 15 & 79 \\
\hline & & $\begin{array}{l}\text { The curricular } \\
\text { instruments are repetitive } \\
\text { and of content reviewing }\end{array}$ & 16 & 19 & 65 \\
\hline & \multirow{2}{*}{$\begin{array}{c}\text { Prescriptive } \\
\text { Teaching }\end{array}$} & $\begin{array}{l}\text { One can say that } \\
\text { education has as } \\
\text { conceptual tradition } \\
\text { just the intellectual }\end{array}$ & 38 & 25 & 37 \\
\hline & & $\begin{array}{l}\text { The current schools need } \\
\text { to change the way it } \\
\text { conceives its Time } \\
\text { (partial } \mathrm{x} \text { integral) }\end{array}$ & 12 & 16 & 72 \\
\hline & \multirow{2}{*}{$\begin{array}{c}\text { Evaluation } \\
\text { method }\end{array}$} & $\begin{array}{l}\text { The student's interest is } \\
\text { only to pass on to the next } \\
\text { grade without worrying } \\
\text { about the knowledge. }\end{array}$ & 6 & 12 & 84 \\
\hline & & $\begin{array}{l}\text { The evaluation system } \\
\text { is the reflection of } \\
\text { the education's } \\
\text { personalization }\end{array}$ & 21 & 16 & 63 \\
\hline
\end{tabular}

1) Level of disagreement expresses the attitudes concerning totally disagree and more disagree than agree; 2) The neutral positioning is described by the attitude of neither disagree nor agree; 3) Levelof agreement expresses attitudes of more agreeing than strongly disagree and agree. Source: Elaboration of the authors.

the respondents, one can then infer that there are robust evidences regarding the traditional educational culture in most of the schools surveyed and that these base their educational assumptions on the liberal pedagogical approach. Therefore, they fit into the fundamentals of the classical positioning of education.

On the other hand, in the context of postmodern society, with reference to the assumptions of the seven knowledges of education of the future, marked based on Edgar Morin's theory, the following results were obtained, as presented in Table 2.

The data relevant to paradigms in contemporary education with a focus on knowledge generation leads to the identification of relevant signs of a tendency towards articulation and the production of knowledge. For $82 \%$ of the respondents, knowledge must be interconnected with the individual's skills and abilities, but $22 \%$ disagree that such interdependence and interactivity of explicit and tacit knowledge is capable of producing some inference in the learning process, 
Table 2. Matrix of analytical logical structure of the modern education dimension.

\begin{tabular}{|c|c|c|c|c|c|}
\hline \multirow{3}{*}{ Dimension } & \multirow{3}{*}{$\begin{array}{l}\text { Variable } \\
\text { analyzed }\end{array}$} & \multirow{3}{*}{ Questionnaire Item } & \multicolumn{3}{|c|}{ Teaching perception } \\
\hline & & & $\begin{array}{c}\text { Level of } \\
\text { Disagreement }\end{array}$ & Neutral & $\begin{array}{c}\text { Level of } \\
\text { Agreement }\end{array}$ \\
\hline & & & $\%$ & $\%$ & $\%$ \\
\hline \multirow{6}{*}{$\begin{array}{l}\text { Modern } \\
\text { Education }\end{array}$} & \multirow{2}{*}{$\begin{array}{l}\text { Knowledge } \\
\text { generation }\end{array}$} & $\begin{array}{l}\text { It is necessary for } \\
\text { education to work in } \\
\text { network, with a } \\
\text { systemic vision }\end{array}$ & 6 & 12 & 82 \\
\hline & & $\begin{array}{l}\text { Knowledge is } \\
\text { intertwined with the } \\
\text { skills and abilities of } \\
\text { the individual }\end{array}$ & 6 & 12 & 82 \\
\hline & \multirow{2}{*}{ Dialogic } & $\begin{array}{c}\text { The school } \\
\text { environment } \\
\text { does not work } \\
\text { as well as it used to }\end{array}$ & 22 & 6 & 72 \\
\hline & & $\begin{array}{l}\text { Dialogue is } \\
\text { fundamental } \\
\text { for the mediation } \\
\text { of knowledge }\end{array}$ & 0 & 0 & 100 \\
\hline & \multirow[b]{2}{*}{$\begin{array}{l}\text { Educational } \\
\text { holism }\end{array}$} & $\begin{array}{l}\text { Society, the school } \\
\text { and the individual } \\
\text { are inseparable }\end{array}$ & 21 & 33 & 46 \\
\hline & & $\begin{array}{l}\text { Transdisciplinarity } \\
\text { has little effect } \\
\text { within its } \\
\text { dependencies }\end{array}$ & 40 & 33 & 27 \\
\hline
\end{tabular}

1) Level of disagreement expresses the attitudes concerning totally disagree and more disagree than agree; 2) The neutral positioning is described by the attitude of neither disagree nor agree; 3) Level of agreement expresses attitudes of more agreeing than strongly disagree and agree. Source: Elaboration of the authors.

and of these $6 \%$ have no opinion formed that the interconnection of these descriptors has in itself such a relevant factor in the process of knowledge acquisition. An interpretation for these results could suggest a paradox as a result of the first item researched, where $82 \%$ of the respondents agree with a networked education and a systemic view of the whole educational process, yet in this analysis it is verified that $12 \%$ of teachers do not have any opinion on the topic.

It can be inferred from the results found that for $46 \%$ of teachers, society, school and the individual are inseparable and that this holistic vision of education takes place through the internalization of team values, ensuring that it works for the purpose of satisfaction of the needs of the whole, not just individual needs. It was also observed that in this variable, these teachers did not know how to opine or did not know the complexity of postmodern education.

The analysis made in the variable referring to the school environment shows us that $72 \%$ of teachers agree that this environment does not work as well as it used to. If the school should be understood as a social environment, consequently it should allow a pleasant interaction between students, teachers and the 
school community. A knowledge-based environment develops this value naturally in a partaking and meaningful way. The data also suggests that the divergence between respondents' opinions is quite significant, since $22 \%$ disagree with this statement and $6 \%$ do not have a formed opinion about the current functionality of the school environment. As far as the dialogic one is concerned, $100 \%$ of respondent teachers affirm that dialogue is essential for the mediation of knowledge. In turn, the questionnaire item referring to transdisciplinarity indicates the complexity of this dimension in the face of the logical practice of disciplinarity.

On the other hand, through the results obtained by the research it is possible to establish some observations between the traditional educational culture and the context of education in post modernity, having as support the characteristics of traditional liberal pedagogy and the complexity of Edgar Morin's postmodern education, those to be highlighted as follows:

- It is noted that there is significant evidence of traditional educational culture based on the assumptions of traditional liberal pedagogy in the schools surveyed;

- The traces of a prescriptive educational system are raised, casted and with repetitive curricular instruments of content of the schools surveyed, with a vision grounded on the conceptual tradition and the customization of education;

- It was observed, when it comes to the student's progression item, in the teacher's perception, that the interest for knowledge is shallow, since the main goal is to go to the next grade being evaluated quantitatively and formally;

- The evidence indicates that the schools studied coexist as the paradox of traditional educational culture in the context of liquid modernity, even considering the reformist movements and the various modernizing educational pedagogical tendencies, whereas traditional education has strong traits in the context of the present school: a conservative, disciplinary environment and far from society.

\section{Final Remarks}

The paradoxes of education, under the focus of the different theoretical lines of approaching, are assumptions that promote an epistemological dialectic to explain the phenomena related to the process of teaching learning. On the other hand, the synthesis taken from these theoretical reflections and their explanatory contributions lead educators to transpose the old to the new educational models. In this context, therefore, one can refute the relationships and conflicts of traditional educational culture and liquid modernity in schools. This antagonism is latent among educators.

On one hand, there is contemporary education in which it is inserted under the perspective of liquid modernity, where holistic (systemic) knowledge leads 
the process of teaching and learning to be inter and transdisciplinary, through understanding the social and cultural dynamics of the student, shaping the knowledge and knowledge required by globalized society. Another point that should stand out is the practices of modern (traditional) education, grounded on the Cartesian (positivist) viewpoint, based on the past fragmentation of know-how and knowledge, often disconnected from reality and creating a social gap by not promoting education of the individual to the present time.

To this end, the empirical evidences of this research indicate that in Brazilian education, the light of the social, economic and cultural context of the rapid and complex transformations of postmodern society, there is still a predominance of traditional liberal pedagogical thinking. It is noted, however, a paradoxical fact about the phenomenon studied: teachers have in mind the movement and principles of the new school, which was considered as the first concrete proposal and conflicting to traditional teaching; however, in the universe of the educational process of the schools investigated, teachers preach rationality, discipline, evaluation and individual interests, that is, they fall within the scope of the traditional school. Therefore, they abdicate the task of agents of transformation by not conducting the process of teaching learning in an inter- and transdisciplinary way, planning and thinking strategies to teach when preparing their class. Thus, it is up to them, in this contemporary scenario, to have the orthodox role of a passive agent in performing pre-assigned classes, structured within the curriculum and determined minute by minute, as it can be observed by the analysis of pedagogical routines. In this way, it is to be inferred that the traditional education paradigms overlap the thoughts and the dynamics of the society inserted in the context of liquid modernity.

\section{Conflicts of Interest}

The authors declare no conflicts of interest regarding the publication of this paper.

\section{References}

Bauman, Z. (1997). Ética pós-moderna. São Paulo: Editora Paulus.

Bauman, Z. (2013). Modernidade líquida. Rio de Janeiro: Editora Zahar.

Canário, R. (2005). A Escola Tem Futuro?Das Promessas às Incertezas. Ed. Artmed.

Foucault, M. (1997). Microfísica do poder (28th ed.). Rio de Janeiro: Paz \& Terra.

Libâneo, J. C. (1984). Democratização da Escola Pública a Pedagogia Crítico Social dos Conteúdos (15th ed.). São Paulo: Loyola.

Lima, J. F. L. (2010). A pedagogia e o cenário pós-moderno: sobre as possibilidades de continuar educando. Educereet Educare: Revista de Educação. Cascabel, 5, 1-12.

Morin, E. (2000). Os sete saberes necessários à educação do futuro. São Paulo: Editora Cortez. https://doi.org/10.20396/etd.v2i3.587

Saviani, D. (1983). Tendências e correntes da educação brasileira. In D. T. Mendes (Ed.), Filosofia da educação no Brasil. Rio de Janeiro: Civilização Brasileira. 